\title{
Traditional Selection Potato Varieties and Their Resistance to the 28-punctata Potato Ladybug Henosepilachna vigintioctomaculata (Coleoptera: Coccinellidae) in the Southern Russian Far East
}

\author{
N.V. Matsishina, P.V. Fisenko, M.V.Ermak, O.A. Sobko, D.I. Volkov, N.G. Boginskaya
}

10.18805/IJARe.AF-694

\begin{abstract}
Background: Henosepilachna vigintioctomaculata is a polytrophic pest, causing the greatest damage to plants from the nightshade family. The study aimed to research the resistance of potato cultivars that are promising for breeding to damage by a potato ladybug in laboratory and field experiments.

Methods: In laboratory experiments, the indicators of fertility, mortality and duration of development, morphological anomalies and the effect of potato varieties on the composition of Epilakhna's hemolymph were studied. The sample consisted of 50 individuals with a slight predominance of females. The experiment used 13 varieties of potatoes.

Result: A specific dependence of the frequency of phytophage anomalies on the variety was revealed. The influence of nutrition on survival and the timing of ontogenesis has been established. The results obtained indicate the high breeding value of the material when recommending it for cultivation in regions with a high number of pests, as well as when creating new varieties.
\end{abstract}

Key words: Breeding, Immunity mechanisms, Pest resistance, Phytophage, Potato ladybug, Potato.

\section{INTRODUCTION}

Currently, there are practically no areas in Russia for the potato and vegetable nightshade crops cultivation that are free of dangerous for them pests and pathogens. A lot of varieties with high consumer qualities and complex resistance to harmful organisms are registered in the State Register of Breeding Achievements (Ivanova and Fasulati, 2016).

From the plant protection point of view, stable varieties most fully solve the problems of preserving crops from damage and protecting the biosphere from pesticide contamination (Vilkova and Fasulati, 2001). Therefore, one of the most important breeding directions should be the creation of forms that reduce the phytophages harmfulness and restrain their mass reproduction. Despite the undoubted relevance of the topic, there is practically no work in the direction of studying the group and complex resistance of potato to the 28-punctata potato ladybug. $H$. vigintioctomaculata is a polytrophic pest, causing the greatest damage to plants from the nightshade family. The nature of the damage is the same for adults and larvae: they furrow the leaves, leaving the veins intact, as a result the leaves wither. As the ages change, the larvae need more and more food and, during the period of their development, each eats an average of $21.2 \mathrm{~cm}^{2}$ of a specific leaf surface. As a result, the productivity of the plant is greatly reduced. In addition, the potato ladybug is a carrier of some diseases and this also causes damage to the crop (Smirnov, 2010). In view of the foregoing, the study aimed to research the resistance of promising for breeding potato cultivars to caused by the potato ladybug damage in laboratory and field experiments.
Federal Scientific Center of Agricultural Biotechnology of the Far East named after A.K. Chaiki, Vologenin-st, 30, Ussuriisk, Primorsky krai, 692539, Russian Federation.

Corresponding Author: N.V. Matsishina, Federal Scientific Center of Agricultural Biotechnology of the Far East named after A.K. Chaiki, Vologenin-st, 30, Ussuriisk, Primorsky krai, 692539, Russian Federation. Email: mnathalie134@gmail.com

How to cite this article: Matsishina, N.V., Fisenko, P.V., Ermak, M.V., Sobko, O.A., Volkov, D.I. and Boginskaya, N.G. (2022). Traditional Selection Potato Varieties and Their Resistance to the 28-punctata Potato Ladybug Henosepilachna vigintioctomaculata (Coleoptera: Coccinellidae) in the Southern Russian Far East. Indian Journal of Agricultural Research. DOI: 10.18805/IJARe.AF-694.

Submitted: 16-09-2021 Accepted: 09-12-2021 Online: 05-01-2022

\section{MATERIALS AND METHODS}

Studies were conducted at the Laboratory of Selection and Genetic Research of Field Crops (A.K. Chaika Federal Research Center for Agrobiotechnology of the Far East) in the period 2019-2021. In laboratory experiments, the indicators of fertility, mortality and development duration were studied. Used beetle larvae of artificial population. The insects were brought up at $25^{\circ} \mathrm{C}$ and $85 \%$ humidity, 16 hours light/day in gauze insulators. In each container larvae from the same family were placed in the amount of 10-15 individuals. Accounting was carried out once every 2 days, it was combined with a change of feed. The average body weight of pupae was determined according to the VIZR recommendations, immediately after pupation. Individual weighings of thirty individuals from each variant of the 
experiment were carried out, with 5 iterations of the experiment (Vilkova et al., 2003).

The classification of morphological anomalies is given according to Yu. A. Prisna (Prisny, 2009). Insects were measured using an MBS-10 stereomicroscope (Zlotin, 1989). Developmental anomalies were taken into account both in adults and in larvae. The frequency of occurrence was calculated.

The influence of potato varieties on the $H$. vigintioctomaculata hemolymph composition was studied using standard methods. Visually healthy individuals without signs of mycosis, bacteriosis and virosis were selected from the artificial population. The sample consisted of 50 individuals, with a slight predominance of females. For staining, Giemsa paint was used (Ribeiro, Brehelin, 2006), the staining was performed according to the Silva et al. method (2002). The study was conducted in 5-10 view fields of the microscope. The quantitative ratio of all hemocytes types was established when viewing 100 cells. The preparations were analyzed under the Levenhuk D740T microscope (Germany) and using the CellProfiler program. The descriptions of Chaika (Chaika, 2017) were used to identify hemocytes.

The field assessment of potato was carried out for three years (2019-2021) in the conditions of the entomophyto pathological site of natural pest and pathogen infestation of the Potato and Vegetable Growing Department of Federal State Budget Scientific Institution
"Federal Scientific Center of Agricultural Biotechnology of the Far East named after A. K. Chaika". When setting up the experiment, the VIZR method was used (Pavlyushin et al., 2005). 13 potato varieties were used in the experiment: Augustine, Dachny, Kazachok, Queen Anne, Smak, Yubilyar, Yantar, Belmonda, Labella, Laperla, Lilly, Red Lady, Sante.

\section{RESULTS AND DISCUSSION}

As a result of a laboratory experiment conducted in 20192021, a specific dependence of the anomalies frequency on the variety was revealed. All anomalies have a combined character, but there is no direct relationship between the totality of their manifestations. We recorded 17 violations of the normal structure: trematelitria, pupal imago, the right middle tibia partial atrophy, non-divergence of the pupal exuvium, pronotum deformity, dystrophy of the middle legs last segments, elytra hematomas, point injuries, brachelitria, complete reduction of the front right foot segments with the metatarsus preservation, gaping elytra suture, reduction of the right hind leg with the thigh base preservation, sixmembered antennae, schistomelia, anomaly of the right and left wings cubital veins, wings deformities with external elytra asymmetry (Fig 1).

When feeding on the Belmonda variety, deformities were observed more often than on the others - in $97.3 \%$ of cases, in addition, anomalies in the development of larvae

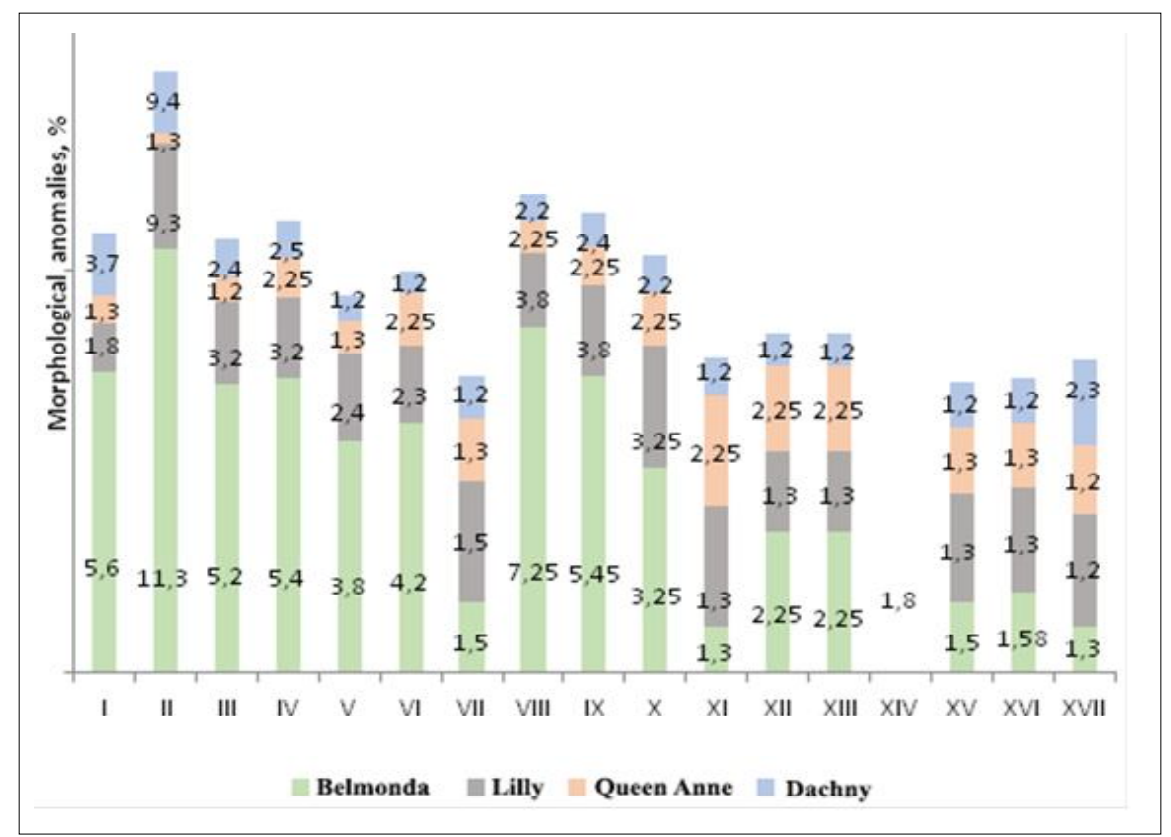

Fig 1: Distribution of morphological anomalies by potato varieties, $\%$.

Explanations. I- Partial atrophy of the right middle tibia; II- Trematelitria; III- The imago has the appearance of a pupa; IV- Larval development abnormalities; V- Detention of the pupal exuvia; VI- Pronotum deformation; VII- Dystrophy of the middle legs last segments; VIII- Elytra hematomas; IX- Point injuries; X- Brachelitria; XI- Complete reduction of the front right leg segments with the metatarsus preservation; XII- Gaping suture elytra; XIII- Reduction of the right hind leg with the preservation of the thigh base; XIVsix-limb antennae; XV- schistomelia; XVI- anomalies of the cubital vein; XVII- deformities of the wings with elytra external asymmetry. $d f=1.38, F=4,87, p \leq 0.01$. 
Traditional Selection Potato Varieties and Their Resistance to the 28-punctata Potato Ladybug Henosepilachna vigintioctomaculata...

were observed on the Belmonda and Lilly varieties. The body became elongated, thin and stretched, parts of the old cuticle remained on the new integuments, the bristles were lost, as well as the structures located at the ends of the legs and mouth. The cuticle took on a uniform, dark gray color and several thoracic segments were dorsally inflated. The autopsy did not show the pathogenesis inherent in the parasite or mycosis development, which allowed us to conclude that the anomaly was non-invasive. Some pupae had areas with abnormally thin cuticles. At the same time, there was a change in pigmentation and the appearance of black spots as a result of hypermelanization. In $12 \%$ of cases on the Belmonda variety, there was a death during molting, in which the larvae remained entangled in old exuvia. The body of the pupa in $10 \%$ for the Lilly variety and in $4 \%$ on the Belmonda was wrinkled and deformed. At the same time, the frequency of individual anomalies - trematelitria, elytra pupoid deformity and elytra hematomas, correlate with those or higher for individuals raised on the Lilly, Dachny and Queen Anna varieties, respectively.

At the same time, a comparison of $H$. vigintioctomaculata hemograms showed that nutrition on potato varieties showing the presence of immunological barriers led to sublethal changes in the hemolymph formula. Thus, the battening of an adult on the Belmonda variety led to pathological enocytoids vacuolization, a decrease in the size and clarity of the nucleus structure and spherulocytes protoplasm. In the Kazachok variety, there was a general cell degeneration, expressed in the displacement of the nuclei to the periphery, as well as in a decrease in the size of the shaped elements themselves. In general, the hemogram of $H$. vigintioctomaculata on the varieties Belmonda, Kazachok, Queen Anna, Lilly, Red Lady, Labella had similar features to the picture described by a number of researchers for the effects of sublethal pesticides doses (Giulianin et al., 2003; Gillund et al., 2011). Nutrition on potato also affected the terms of

Table 1: Terms of potato ladybug postembryonic development on different potato varieties in laboratory conditions (2019-2021).

\begin{tabular}{lcccccc}
\hline \multirow{2}{*}{ Variety } & \multicolumn{4}{c}{ Larva age, day } & \multirow{2}{*}{ Pupae, day } & Total, day \\
\cline { 2 - 5 } & I & II & III & IV & & \\
\hline Smack & $5.17 \pm 0.97$ & $4.25 \pm 1.43$ & $4.50 \pm 1.45$ & $4.00 \pm 0.97$ & $5.25 \pm 1.48$ & $23.17 \pm 3.41$ \\
Yubilyar & $3.66 \pm 0.24$ & $4.25 \pm 0.24$ & $3.66 \pm 0.24$ & $3.66 \pm 0.24$ & $4.75 \pm 1.48$ & $21.50 \pm 1.45$ \\
Kazachok & $5.00 \pm 1.45$ & $5.08 \pm 1.45$ & $5.17 \pm 0.97$ & $5.17 \pm 0.48$ & $4.33 \pm 1.48$ & $24.75 \pm 1.45$ \\
Sante & $3.50 \pm 1.45$ & $4.75 \pm 1.45$ & $3.50 \pm 1.45$ & $3.50 \pm 0.48$ & $6.25 \pm 0.48$ & $21.50 \pm 2.91$ \\
Dachny & $4.33 \pm 1.45$ & $4.17 \pm 1.45$ & $4.33 \pm 0.48$ & $4.33 \pm 0.48$ & $3.33 \pm 1.48$ & $20.5 \pm 4.37$ \\
Augustine & $4.92 \pm 0.48$ & $4.83 \pm 0.24$ & $4.12 \pm 0.24$ & $3.00 \pm 0.48$ & $5.17 \pm 1.48$ & $22.10 \pm 0.24$ \\
Yantar & $5.12 \pm 0.24$ & $5.50 \pm 0.24$ & $5.17 \pm 0.24$ & $4.35 \pm 0.24$ & $5.33 \pm 1.48$ & $25.33 \pm 0.72$ \\
Laperla & $3.00 \pm 0.24$ & $3.00 \pm 0.24$ & $2.00 \pm 0.24$ & $3.00 \pm 0.24$ & $6.03 \pm 1.48$ & $17.06 \pm 1.45$ \\
Lilly & $3.17 \pm 0.24$ & $3.08 \pm 0.24$ & $2.17 \pm 0.24$ & $2.00 \pm 0.24$ & $14.67 \pm 0.48$ & $25.08 \pm 0.24$ \\
Queen Anne & $1.58 \pm 0.24$ & $3.08 \pm 0.24$ & $1.33 \pm 0.24$ & $1.33 \pm 0.24$ & $17.67 \pm 0.48$ & $24.80 \pm 0.72$ \\
Red Lady & $2.76 \pm 0.24$ & $2.00 \pm 0.24$ & $2.00 \pm 0.24$ & $2.00 \pm 0.24$ & $17.00 \pm 0.48$ & $25.76 \pm 1.21$ \\
Labella & $2.36 \pm 0.24$ & $2.00 \pm 0.24$ & $2.00 \pm 0.24$ & $2.00 \pm 0.24$ & $17.00 \pm 0.24$ & $25.36 \pm 0.24$ \\
Belmonda & $6.33 \pm 0.24$ & $7.08 \pm 0.24$ & $7.17 \pm 0.24$ & $8.00 \pm 0.24$ & $22.67 \pm 0.24$ & $51.25 \pm 1.21$ \\
\hline
\end{tabular}

Table 2: Weight indicators of potato ladybug pupae in the laboratory experiment.

\begin{tabular}{|c|c|c|c|c|c|}
\hline \multirow{3}{*}{ Variety } & \multicolumn{5}{|c|}{ Number of experiment iterations } \\
\hline & \multicolumn{5}{|c|}{ Pupal weight, $\mathrm{mg}$} \\
\hline & 1 & 2 & 3 & 4 & 5 \\
\hline Smack & $54.1 \pm 1.12$ & $55.2 \pm 2.14$ & $53.2 \pm 1.12$ & $54.1 \pm 1.12$ & $55.3 \pm 1.12$ \\
\hline Yubilyar & $42.4 \pm 1.12$ & $41.3 \pm 2.14$ & $40.2 \pm 1.12$ & $41.4 \pm 1.12$ & $42.5 \pm 1.12$ \\
\hline Kazachok & $32.2 \pm 1.12$ & $31.8 \pm 2.14$ & $32.3 \pm 1.12$ & $31.8 \pm 1.12$ & $33.4 \pm 1.12$ \\
\hline Sante & $42.1 \pm 1.12$ & $42.3 \pm 2.14$ & $42.5 \pm 1.12$ & $41.8 \pm 1.12$ & $42.3 \pm 1.12$ \\
\hline Dachny & $42.1 \pm 1.12$ & $42.2 \pm 2.14$ & $42.2 \pm 1.12$ & $41.3 \pm 1.12$ & $42.3 \pm 1.12$ \\
\hline Augustine & $35.4 \pm 1.12$ & $35.5 \pm 2.14$ & $34.9 \pm 1.12$ & $35.3 \pm 1.12$ & $35.5 \pm 1.12$ \\
\hline Yantar & $44.6 \pm 1.12$ & $44.3 \pm 2.14$ & $44.5 \pm 1.12$ & $44.2 \pm 1.12$ & $44.2 \pm 1.12$ \\
\hline Laperla & $31.3 \pm 1.12$ & $31.3 \pm 2.14$ & $30.9 \pm 1.12$ & $30.9 \pm 1.12$ & $31.2 \pm 1.12$ \\
\hline Lilly & $32.1 \pm 1.12$ & $32.2 \pm 2.14$ & $32.2 \pm 1.12$ & $31.8 \pm 1.12$ & $31.8 \pm 1.12$ \\
\hline Queen anne & $33.2 \pm 1.12$ & $33.2 \pm 2.14$ & $33.2 \pm 1.12$ & $33.4 \pm 1.12$ & $33.4 \pm 1.12$ \\
\hline Red lady & $32.1 \pm 1.12$ & $32.2 \pm 2.14$ & $32.3 \pm 1.12$ & $32.3 \pm 1.12$ & $32.3 \pm 1.12$ \\
\hline Labella & $32.3 \pm 1.12$ & $32.1 \pm 2.14$ & $32.2 \pm 1.12$ & $32.3 \pm 1.12$ & $32.2 \pm 1.12$ \\
\hline Belmonda & $12.5 \pm 1.12$ & $12.3 \pm 2.14$ & $11.9 \pm 1.12$ & $12.2 \pm 1.12$ & $12.5 \pm 1.12$ \\
\hline
\end{tabular}




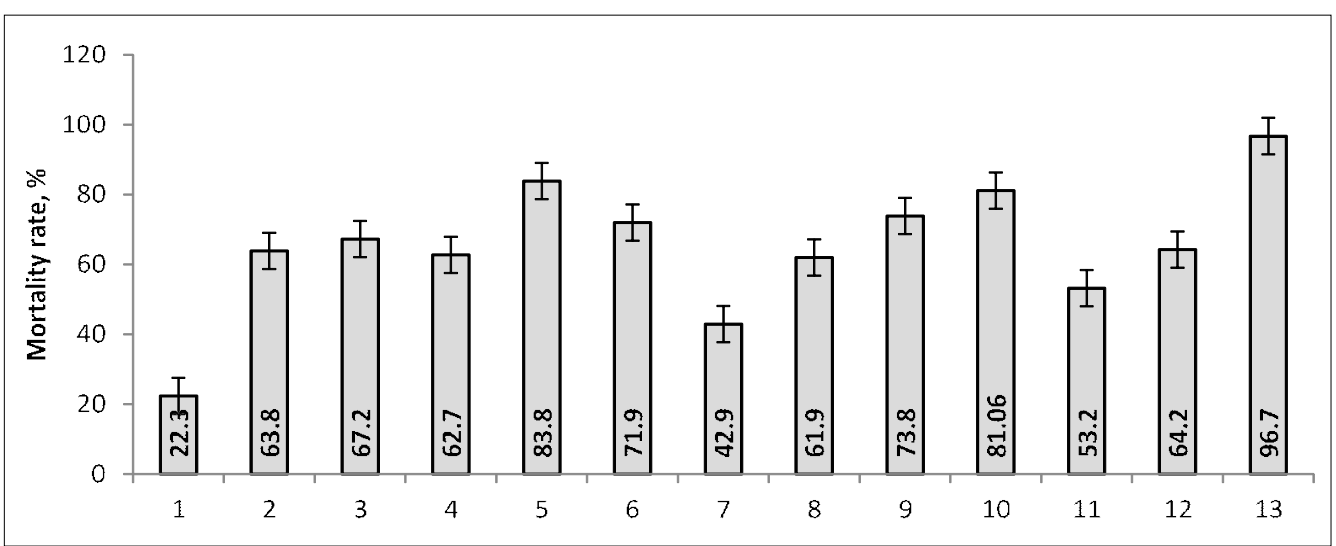

Fig 2: Mortality of the 28-punctata potato ladybug larvae when feeding on potato varieties in a laboratory experiment, \%. Notes: 1- Smack; 2- Yubilyar; 3- Kazachok; 4- Sante; 5- Dachny; 6- Augustine; 7- Yantar; 8- Laperla; 9- Lilly; 10- Queen Anne; 11- Red Lady; 12- Labella; 13- Belmonda. $\mathrm{Df}=1.38, \quad \mathrm{~F}=9.38, \mathrm{p} \leq 0.01$.

ontogenesis, survival and fat-feeding nutrition of the $H$. vigintioctomaculata (Table 1, 2, Fig 2). According to the average long-term data, the Smak variety became the most optimal for feeding, growth and development of all potato ladybug age stages. It has the lowest mortality rate and the highest fecundity (Matsishina et al., 2019). The least favorable varieties for the potato ladybug feeding are Queen Anne, Lilly, Dachny and Kazachok, which are characterized by the maximum mortality at acceptable shifts in ontogenetic terms. As a result of the study, the Belmonda variety which demonstrated a complex of immune barriers to the pest was distinguished. When feeding this variety, the highest mortality rate $(100 \%)$ was recorded with the extension of the ontogenesis time frame.

The maximum values of pupal weight were observed for the varieties Smak $(\bar{a}=54.38 \mathrm{mg})$ and Yubilyar $(\bar{a}=41.5$ $\mathrm{mg}$ ). The minimum values were observed for the Belmonda variety $(\bar{a}=12.28 \mathrm{mg})$. In the remaining varieties, uniform weight distribution was observed, which is consistent with the indicators of the ontogenesis and mortality terms. All of the above is a reliable criterion for high resistance of the Belmonda variety to $H$. vigintioctomaculata (Fasulati and Ivanova, 2015; Shelley, 2000).

The results of laboratory experiments are also confirmed by studies in the entomophytopathological site conditions (ETHU) of potato ladybug natural settlement (Table 3). The largest number of ovipositors and eggs in them on the plant was observed in the Yubilyar variety (4/401), the smallest in the Lilly variety (1.5/23.6).

The maximum number of older ages larvae and adults is recorded for the Smak variety, the minimum - for Red Lady in the case of adults and Labella - in the case of larvae. The highest damage score was observed on the Kazachok variety (5.0), the lowest - on the Labella variety (2.2). The Kazachok (5 damage points), Queen Anna (3.1 points) and Rad Lady (3.1 points) varieties showed signs of the presence

Table 3: Results of the varieties stability at the potato ladybug natural settlement study.

\begin{tabular}{|c|c|c|c|c|c|c|c|c|}
\hline \multirow[b]{2}{*}{ Variety } & \multicolumn{3}{|c|}{ Pest population } & \multirow{2}{*}{$\begin{array}{c}\text { Damage } \\
\text { Score }\end{array}$} & \multirow{2}{*}{$\begin{array}{c}\text { Necrosis } \\
\text { under the } \\
\text { ovipositor (\%) }\end{array}$} & \multirow{2}{*}{$\begin{array}{l}\text { Number } \\
\text { of eyes } \\
\text { (piece) }\end{array}$} & \multirow{2}{*}{$\begin{array}{c}\text { Number of } \\
\text { additional } \\
\text { stems (piece) }\end{array}$} & \multirow{2}{*}{$\begin{array}{c}\text { Increase } \\
\text { in yield } \\
(\mathrm{kg})\end{array}$} \\
\hline & $\begin{array}{c}\text { Oviposition } \\
\text { (specimen/plant) }\end{array}$ & $\begin{array}{c}\text { Larvae III-IV } \\
\text { (instance/plant) }\end{array}$ & $\begin{array}{c}\text { Imago } \\
\text { (instance/plant) }\end{array}$ & & & & & \\
\hline Smack & $16.0 \pm 0.48$ & $712 \pm 1.45$ & $42.4 \pm 0.24$ & 4.5 & 5.3 & $9.05 \pm 0.24$ & $3.5 \pm 0.24$ & 100 \\
\hline Yubilyar & $14.0 \pm 0.48$ & $312.5 \pm 1.45$ & $31.2 \pm 0.24$ & 4.5 & 10.2 & $8.85 \pm 0.24$ & $2.3 \pm 0.24$ & -2066 \\
\hline Kazachok & $10.0 \pm 0.48$ & $107 \pm 1.45$ & $30.4 \pm 0.24$ & 5.0 & 74.3 & $8.3 \pm 0.24$ & $3.5 \pm 0.24$ & 28266.7 \\
\hline Sante & $2.5 \pm 0.48$ & $78.5 \pm 1.45$ & $12.28 \pm 0.24$ & 3.5 & - & $6.2 \pm 0.24$ & $4.2 \pm 0.24$ & 2400 \\
\hline Dachny & $2.1 \pm 0.48$ & $91.5 \pm 1.45$ & $24.2 \pm 0.24$ & 4.5 & - & $7.45 \pm 0.24$ & $0 \pm 0.24$ & -4333.4 \\
\hline Augustine & $2.2 \pm 0.48$ & $110 \pm 1.45$ & $23.1 \pm 0.24$ & 4.5 & 12.2 & $8.2 \pm 0.24$ & $0 \pm 0.24$ & -633.4 \\
\hline Yantar & $3.0 \pm 0.48$ & $57 \pm 1.45$ & $25.4 \pm 0.24$ & 4.5 & - & $8.36 \pm 0.24$ & $0 \pm 0.24$ & 0 \\
\hline Laperla & $3.0 \pm 0.48$ & $38.5 \pm 1.45$ & $12.28 \pm 0.24$ & 3.2 & - & $7.14 \pm 0.24$ & $0 \pm 0.24$ & -3600 \\
\hline Lilly & $1.5 \pm 0.48$ & $35.5 \pm 1.45$ & $11.45 \pm 0.24$ & 3.1 & - & $7.45 \pm 0.24$ & $0 \pm 0.24$ & -2466.7 \\
\hline Queen Anne & $1.5 \pm 0.48$ & $39.5 \pm 1.45$ & $20.1 \pm 0.24$ & 3.1 & 75 & $5.85 \pm 0.24$ & $4.2 \pm 0.24$ & 3733.3 \\
\hline Rad Lady & $2.0 \pm 0.48$ & $50.5 \pm 1.45$ & $2.6 \pm 0.243$ & 3.1 & 72.3 & $8.55 \pm 0.24$ & $4.3 \pm 0.24$ & 1266.7 \\
\hline Labella & $1.5 \pm 0.48$ & $34.5 \pm 1.45$ & $4.8 \pm 0.24$ & 2.2 & - & $5.9 \pm 0.24$ & $1.2 \pm 0.24$ & -2906.7 \\
\hline Belmonda & - & - & $0.5 \pm 0.24$ & 0.1 & н/я & $6.3 \pm 0.24$ & $5 \pm 0.24$ & 7866.7 \\
\hline
\end{tabular}

Note: negative values indicate crop loss. 


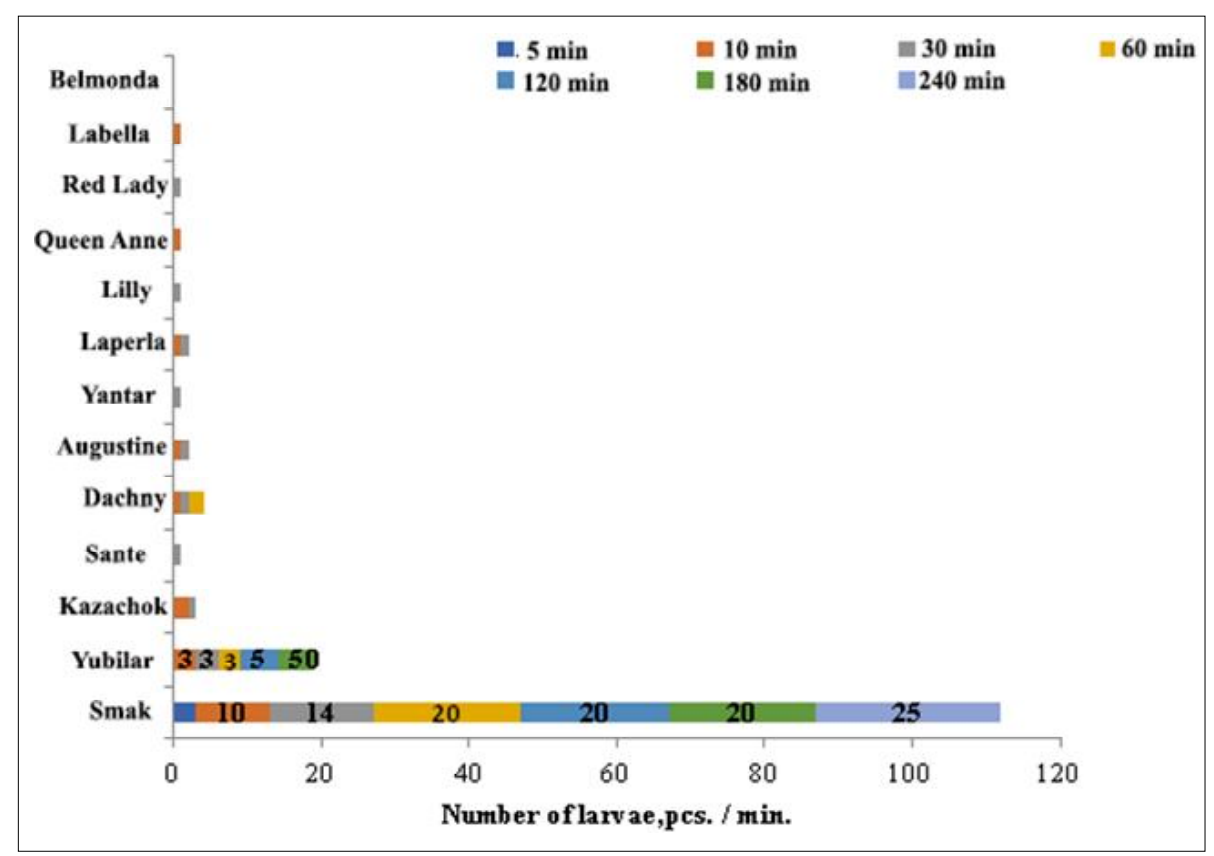

Fig 3: Distant orientation of potato ladybug larvae to potato varieties. $\mathrm{df}=1.38, \mathrm{~F}=5.12, \mathrm{p} \leq 0.05$.

of antibiosis and resistance to damage by phytophagous. Necrosis under the ovipositor and the appearance of additional stems were noted. For the Belmonda variety, manifestations of antixenosis were also recorded, which is expressed in the fact that the plants of this variety were not selected by the ladybug either for food or for laying eggs.

Among other things, we conducted experiments to study the distant orientation of larvae of the III-IV instars of the potato ladybug (Fig 3) to potato varieties. For food, they were offered leaves of the studied varieties, laid out in a gauze insulator at an equal distance from the larvae and each other. The study sample consisted of 25 individuals, the exposure time was 4 hours and the number of experiment iterations was 5 . It was found that the variety Belmonda is unattractive for larvae. During the experiment, it was not selected for nutrition in any of the experiment iterations. At the same time, the Smack variety was absolutely attractive. The larvae that began to feed on other varieties soon left them, moving to the leaves of the Smack variety. To a lesser extent, they chose the Yubilyar, Dachny, Augustine and Kazachok varieties. The varieties Sante, Yantar, Lilly, Red Lady and Labella were selected on average by one individual from the sample.

All existing potato varieties are damaged to some extent by $H$. vigintioctomaculata. The differences between them in the degree of damage are to some extent related to the biochemical composition, characteristics of leaves and regenerative capacity (Nazarenko et al., 2002). Glycoalkaloids are also teratogens, causing various deformations and deviations in the development of insects (Chen et al., 2018).
The cause of morphological deviations should be sought in the physiology of insects. All abnormalities are associated with impaired embryogenesis (Telang et al., 2002, Miranda et al., 2016; Burand, Hunter, 2013; Madhavi, 2019). According to the views of Steinhaus (1952), disturbances in the morphology of the exoskeleton are non-infectious diseases of the insect organism. In our opinion, these may be features of the interaction of a phytophage and a plant, expressed in the form of antibiosis and antixenosis (Shapiro et al., 1986). Phytophages choose plants of certain species and varieties as a food source, which is facilitated by compounds with repellent and attractant activity. This activity can be detected by the behavior of the larvae, insects spend much more time in search of food on resistant varieties of plants than on unstable ones (Islam et al., 2011; Umamaheswari et al., 2021).

\section{CONCLUSION}

Thus, the following conclusions can be drawn from the analysis of the data obtained by us:

1. A specific dependence of the frequency of phytophage abnormalities on the variety was revealed, when feeding on the Belmonda variety, deformities were observed in $97.3 \%$ of cases;

2. It was found that the nature of nutrition affects the ontogenesis timing and survival. The Smak variety is the most optimal for battening, growth and development of all age stages. The highest mortality rate was recorded on the Belmonda variety, the least favorable for nutrition were the varieties Queen Anne, Lilly, Dachny and Kazachok. 
Traditional Selection Potato Varieties and Their Resistance to the 28-punctata Potato Ladybug Henosepilachna vigintioctomaculata...

3. The laboratory results are correlated with the field experiment data. The presence of antixenosis was recorded for the Belmonda variety and in natural conditions, phytophage does not choose these plants either for food or for laying eggs. In the Kazachok, Queen Anne and Red Lady varieties, necrosis of the tissues under the ovipositor was observed. In the Kazachok variety, with a high lesion of the tops (5 points), the largest increase in yield was observed, which also indicates the presence of resistance repair mechanisms.

4. The results obtained indicate the high breeding value of the studied material when recommending them for cultivation in regions with a high pest population and when creating new varieties.

\section{ACKNOWLEDGEMENT}

The research was carried out using a grant in the form of a subsidy from the Federal budget in order to create and implement modern technologies in the agro-industrial complex based on developments of scientific and educational organizations in the framework of the implementation of the Russian Federation President Decree of July 21, 2016 No. 350 "On measures to implement state scientific and technical policy in the interests of rural development economy", including with the participation of world-class genomic research centers.

\section{Conflict of interest}

The authors declare no conflict of interest.

\section{REFERENCES}

Burand, J.P. and Hunter, W.B. (2013). RNAi: Future in insect management. J. Invertebrate Pathol. 112: 68-74. DOI: 10.1016/ j.jip.2012.07.012.

Chaika, S. Yu. (2017). Insect histology. Moscow. (In Russian).

Chen, X. and Lewandowska, D., Armstrong, M.R., Baker, K., Lim, T.Y., Bayer, M., Harrower, B., McLean, K., Jupe, F., Witek, K., Lees, A.K., Jones, J.D., Bryan, G.J. and Hein, I. (2018). Identification and rapid mapping of a gene conferring broadspectrum late blight resistance in the diploid potato species Solanum verrucosum through DNA capture technologies. Theor. Appl. Gen. 131(6): 1287-1297. doi.org/10.1007/s00122-018-3078-6.

Fasulati S.R., Ivanova O.V. (2015). Sustainable varieties as the basis for integrated protection of potatoes from the Colo rado potato beetle. Potato protection. 2: 32-35. (In Russian)

Gillund, F., Hilbeck, A. and Wikmark, O.G. (2011). Genetically Modified Potato with Increased Resistance to P. infestans - Selecting Test Species for Environmental Impact Assessment on Non-Target Organisms: Biosafety Report 2011/05/ GenØk - Centre for Biosafety. Troms $\varnothing$, Norway.

Giulianini, P.G., Bertolo, F., Battistella, S. and Amirante, G.A. (2003). Ultrastructure of the hemocytes of Cetonischema aeruginosa larvae (Coleoptera, Scarabaeidae): involvement of both granulocytes and oenocytoids in vivo phagocytosis. Tissue Cell. 35(4): 243-251. DOI: 10.1016/s0040-8166 (03)00037-5.
Islam, K., Islam, M.S. and Ferdousi, Z. (2011). Ñontrol of Epilachna vigintioctopuntata Fab. (Coleoptera: Coccinellidae) using some indigenous plant extracts. J. Life Earth Sci. 6: 7580. DOI:10.3329/jles.v6i0.9725.

Ivanova, O.V. and Fasulati, S.R. (2016). Principles and methods of selection of potato and vegetable nightshade crops resistant to the Colorado potato beetle. Plant Protection and Quarantine. 10: 12-16. (In Russian).

Madhavi, M., Babu, R.G. and Srinivas, V. (2019). Morphological abnormalities of betulinic acid from Ziziphus jujuba against the Callasobruchus Chinensis (Coleoptera: Bruchidae). Biosci. Biotech. Res. Asia. 16(2):411-416. DOI: http:// dx.doi.org/10.13005/bbra/2756.

Matsishina, N.V., Shaybekova, A.S., Boginskaya, N.G., Sobko, O.A., Volkov, D.I. and Kim, I.V. (2019). Preliminary study of traditional selection potato varieties resistance for potatoes ladybug Henosepilachna vigintioctomaculata (Motschulsky, 1857 ) in the Primorsky territory. Vegetable Crops of Russia. 6:116-119. https://doi.org/10.18619/2072-91462019-6-116-119 (In Russian.)

Miranda, M.P., Yamamoto, P.T., Garcia, R.B., Lopes, J.P. and Lopes, J.R. (2016) Thiamethoxam and imidacloprid drench applications on sweet orange nursery trees disrupt the feeding and settling behaviour of Diaphorinacitri (Hemiptera: Liviidae). Pest. Manag. Sci. 72: 1785-1793. DOI: 10.1002/ ps.4213.

Nazarenko, E.A., Skryshevskaya, I.V., Korpan, Ya.I., Nazarenko, E.A., Skryshevskaya, I.V. and Korpan, Ya. I. (2002). Potato glycoalkaloids: dissemination, physical and chemical properties, toxicity and methods of detection. Biopolymers and Cell. 6(18): 478-4840. (In Russian.)

Pavlyushin, V.A., Vilkova, N.A., Sukhoruchenko, G.I., Fasulati, S.R., Nadykta, V.D., Ismailov, V. Ya. and Yakovleva I.N. (2005). Methodological recommendations for the indication and monitoring of the processes of the Colorado potato beetle adaptation to genetically modified potato varieties. St. Petersburg. (In Russian).

Prisny, U.A. (2009). Classification of morphological anomalies of the beetles (Coleoptera). Belgorod State University Scientific Bulletin. Natural Sciences. 11(9(1): 72-81. (In Russian.)

Ribeiro, C. and Brehelin, M. (2006). Insect haemocytes: what type of cell is that? J. Insect Physiol. 52(5): 417-429. DOI: 10.1016/ j.jinsphys.2006.01.005.

Shapiro, I. D., Vilkova, N.A. and Slepyan, E.I. (1986). Plant immunity to pests and diseases. Leningrad. (In Russian).

Shelley, J. (2000). Breeding for Disease Resistance in Potato. Plant Breed. Rev. 19: 69-155.

Silva, J.E.B., Boleli, I.C. and Simoes, Z.L.P. (2002). Hemocyte types and total and differential count in unparasitized and parasitized Anastrepha obliqua (Diptera, Tephritidae) larvae. Braz. J. Biol. 62: 689-699. DOI: 10.1590/s151969842002000400017.

Smirnov, Yu. V. (2010). Analysis of the phytosanitary risk of the 28punctata potato ladybug Henosepilachna vigintioctomaculata (Motsch.) for the territory of the Russian Federation. Moscow. (In Russian).

Steinhaus, E. (1952). Pathology of Insects. Moscow. (In Russian). 
Traditional Selection Potato Varieties and Their Resistance to the 28-punctata Potato Ladybug Henosepilachna vigintioctomaculata...

Telang, A., Buck, N.A. and Wheeler, D.E. (2002). Response of storage protein levels to variation in dietary protein levels. J. Insect Physiol. 48(11): 1021-1029. DOI: 10.1016/ s0022-1910(02)00190-7.

Umamaheswari, P., Gayathri, N.K. and Subbarao, M. (2021). Effect of nitrogen fertilizer doses and pre sowing seed treatments on yield and yield attributing characters in foxtail millet (Setaria italica L. Beauv). Indian Journal of Agricultural Research. 55: 634-638.
Vilkova, N.A. and Fasulati, S.R. (2001). Variability and adaptive microevolution of phytophagous insects in an agroecosystem in connection with the immunogenetic properties of forage plants. Proceedings of the Russian Entomological Society. 72: 107-128. (In Russian).

Vilkova, N.A., Asyakin, B.P., Nefedova, L.I., Vereshchagina, A.B., Ivanova, O.V., Razdoburdin, V.A., Fasulati, S.R. and Yusupov, T.M. (2003). Methods of assessing agricultural crops for group resistance to pests. St. Petersburg.

Zlotin A.Z. (1989). Technical entomology. Kiev, (In Russian). 